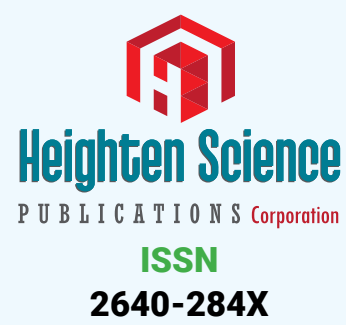

2640-284X
*Address for Correspondence: Gabriele Cioni, Department of Experimental and Clinical Medicine, AOU Careggi, University of Florence, Italy, Email: gabriele.cioni@unifi.it; gabrielec.83@gmail.com

Submitted: 19 December 2016

Approved: 13 March 2017

Published: 15 March 2017

Copyright: @ 2017 Cioni G, et al. This is an open access article distributed under the Creative Commons Attribution License, which permits unrestricted use, distribution, and reproduction in any medium, provided the original work is properly cited

Keywords: Lipoprotein apheresis; Thrombophilia lipoprotein; (a)Endothelial dysfunction peripheral arterial tonometry TEXT

Check for updates
Case Report

\section{Recurrent Cardiac Events Driven by Prothrombotic Burden in a Patient Undergoing Lipoprotein Apheresis for High Lp(a) Levels}

\author{
Gabriele Cioni ${ }^{1 *}$, Rossella Marcucci ${ }^{1}$, Rosanna Abbate ${ }^{1}$ and \\ Giovanna D'Alessandri² \\ ${ }^{1}$ Department of Experimental and Clinical Medicine, AOU Careggi, University of Florence, Italy \\ ${ }^{2}$ SIMT, USL 3, Pistoia, Italy
}

\section{ABSTRACT}

Introduction: Lipoprotein (a) $[\mathrm{Lp}(\mathrm{a})]$ is a marker for cardiovascular disease, involved in pathogenesis and progression of atherosclerosis. In selected high-risk patients, lipoprotein-apheresis could optimize secondary prevention and improve prognosis.

Aim: We presented the case of a 49-year-old man with high lipoprotein (a) levels and recurrent cardiac adverse events, despite maximal pharmacological therapy.

Case report: Four years before the admission at our Centre, he presented an anterior STEMI, treated with angioplasty and implantation of a drug eluting stent on left anterior descending artery, at the age of 47 years, in September 2012; one month later, the patients presented a new episode of angina, and exams showed a critical stenosis in the right coronary artery, treated by angioplasty and implantation of drug eluting stent. Because of high $\mathrm{Lp}(\mathrm{a})$ plasma levels, patient was subsequently on regularly 7-10 day lipoprotein apheresis.

Results and discussion: A thrombophilic screening was performed, showing the simultaneous presence of heterozygous V Leiden mutation and prothrombin G20210A mutation. He referred to our Centre in order to optimize therapy; we performed an endothelial function assessment showing a severe dysfunctional pattern.

Because of these findings, we prescribed dual antiplatelet therapy, and we added omega-3 fatty acids and association with nicotinic acid/laropiprant. According with current guidelines, considering the high risk of bleeding, we preferred not to administer anticoagulant therapy. At 6-month and 1-year follow up the patient continued lipoprotein apheresis and was asymptomatic for other cardiovascular events.

Conclusions: The assessment for the eventual presence of thrombophilia might become a useful tool in clinical practice for high-risk selected patients.

\section{INTRODUCTION}

Lipoprotein (a) [Lp(a)] is considered a marker for cardiovascular disease and it is involved in pathogenesis and progression of atherosclerosis [1]. Several evidences showed that elevated $\mathrm{Lp}(\mathrm{a})$ levels were a risk factor for a variety of atherosclerotic and thrombotic disorders [2]; in particular, high $\mathrm{Lp}(\mathrm{a})$ levels were associated to an increased risk of myocardial infarction and [3,4]. A meta-analysis by Sofi et al., showed the relationship between Lp(a) and venous thrombosis [5]. Therefore, in selected highrisk patients, lipoprotein-apheresis could be added to standard therapy to optimize secondary prevention and improve prognosis [6,7].

Aim

The aim of this study was to evaluate the usefulness of a thrombophilic screening 
in a high risk patients presenting recurrent cardiac adverse events, despite maximal pharmacological therapy and the onset of lipoprotein apheresis treatment.

\section{CASE REPORT}

We presented the case of a 49-year-old man with high lipoprotein (a) levels and recurrent cardiac adverse events, despite maximal pharmacological therapy, admitted to the Transfusional-Apheretic Centre (SIMT), USL3 and Pistoia Hospital. The patient gave his informed consent; this study respects the Helsinki declaration.

\section{Cardiovascular risk assessment}

He suffered from hypertension at an early age and, at the time of the onset of lipoprotein apheretic therapy, he presented good blood pressure control with ramipril and carvedilol. Because of elevated levels of LDL-c and triglycerides he assumed therapy with rosuvastatin $40 \mathrm{mg}$ per day. He was also overweight (BMI=26.2); he was not diabetic and he did never smoke. In the Table 1 we described the lipid profile before and after the onset of statin therapy.

Five years before he underwent to ultrasound assessment for atherosclerosis at common carotid and femoral arteries, evidencing the presence of a non-occlusive peripheral atherosclerosis; therefore, he started therapy with aspirin at $100 \mathrm{mg} /$ day, according to current guidelines [8].

As for family history of heart disease, his father died after a fatal heart attack at the age of 44 years, while his brother, at the age of 45 years of age, had suffered from an ischemic stroke without neurological sequelae.

\section{Description of cardiac events}

In the September 2012, at the age of 47 y.o., the patient had the first cardiac thrombotic event, on aspirin and statin therapy; in particular, he suffered from an anterior STEMI treated with angioplasty and implantation of a drug eluting stent on left anterior descending artery. During the hospitalization, the patient did not show complications. However, one month after discharge, the patient presented a new episode of angina; further investigations showed the presence of a critical stenosis in the right coronary artery, subsequently treated by angioplasty and implantation of drug eluting stent. This lesion was not previously detected.

Further examinations found elevated Lp(a) plasma levels ( $90 \mathrm{mg} / \mathrm{dL})$. $\mathrm{Lp}(\mathrm{a})$ levels were measured by an immune-nephelometric method (LPAX IMMAGE Beckman Coulter); values $\geq 50 \mathrm{mg} / \mathrm{dL}$ were considered abnormal. Therefore, according to the American Society for Apheresis (ASFA) guidelines [9], from January 2013 the patient started lipoprotein apheresis treatment. The therapeutic program included a procedure every 7-10 days; lipoprotein apheresis was performed by the H.E.L.P. (Plasmat Futura, B.Braun, Melsungen, Germany) technique. The mean blood volume processed per each session was approximately $8000 \mathrm{ml}$ of plasma. HELP technique was able to reduce LDL-c and Lp(a) by at least $70 \%$. Patient suspended ramipril and this drug was replaced by an AT1 inhibitor for the risk of a bradykinine syndrome.

Despite the apheretic therapy, one month later the patient was symptomatic for angina at rest. A new echocardiogram showed normal chambers diameters and

\begin{tabular}{|c|c|c|c|c|c|}
\hline & Total -c & LDL-c & HDL-c & TG & VLD-c \\
\hline Before statin therapy & 280 & 172 & 50 & 290 & 58 \\
\hline During statin therapy & 165 & 93 & 52 & 100 & 20 \\
\hline \multicolumn{6}{|c|}{$\begin{array}{l}\text { Total cholesterol, total-c: LDL cholesterol, LDL-c; HDL cholesterol, HDL-c; triglycerides, TG; VLDL } \\
\text { Cholesterol, VLDL-c } \\
\text { Data are expressed in } \mathrm{mg} / \mathrm{dL}\end{array}$} \\
\hline
\end{tabular}


ventricular function, without valve disease; a myocardial perfusion scintigraphy was positive for a defect of uptake in LAD territory. The next angiogram showed a new occlusion of the previously treated vessel, and the patient performed a coronary artery bypass graft.

\section{RESULTS}

Because of his cardiovascular risk and family history, a thrombophilic screening was performed; the examination showed the simultaneous presence of heterozygous V Leiden mutation and prothrombin G20210A mutation. Other tests, investigating the presence of antiphospholipid antibodies or lupus anticoagulant, were negative; levels of antithrombin, $\mathrm{S}$ protein and $\mathrm{C}$ protein were within normal range.

In order to optimize drug therapy and cardiovascular profile, the patient referred to our Centre for Vascular Function, Careggi Hospital. He underwent assessment of endothelial function by peripheral arterial tonometry (EndoPAT $2000^{\mathrm{TM}}$ device, Itamar Medical LTD Caesarea, Israel); the exam showed a severely dysfunctional vascular pattern (LnRHI $=0.2$, n.v. >0.4). Test assessing platelet function showed a platelet inhibition, according to current therapy with aspirin and clopidogrel.

Because of these findings, we optimized drug therapy in order to reduce cardiovascular risk and improve endothelial function. Therefore, we prescribed dual antiplatelet therapy, and we added omega-3 fatty acids and nicotinic acid/laropiprant. According with current guidelines, considering the high risk of bleeding, we preferred not to administer anticoagulant therapy. At 6-month and 1-year follow up the patient continued lipoprotein apheresis and was asymptomatic for new cardiovascular recurrences. According to results of HPS2-THRIVE Study [10], nicotinic acid/ laropiprant had been withdrawn from the market in 2013, and patient suspended this therapy.

\section{DISCUSSION}

This case highlights the role of thrombophilia in influencing the therapeutic response and the risk of recurrent cardiovascular events. Current literature lacks provide evidence of causality between the presence of thrombophilia and cardiovascular events [11] and guidelines discourage the assessment of genetic testing for thrombophilia $[12,13]$; however, patients with a hereditary protein $\mathrm{S}$, protein $\mathrm{C}$ or antithrombin deficiency had a high absolute risk for venous thromboembolism [14]. Moreover, hereditary thrombophilia was frequently reported in young patients [15] with acute coronary syndromes.

The presence of endothelial dysfunction is a well-known cardiovascular risk factor, associated with recurrent cardiac events and a poor prognosis [16,17].

Evidences showed that Lp(a) levels are positively associated with CAD events; moreover, pro-atherogenic, pro-thrombotic and anti-fibrinolytic activities of high $\mathrm{Lp}(\mathrm{a})$ levels, in addition to thrombophilic alterations, could facilitate the occurrence and progression of atherosclerotic damage and increase the risk of coronary events [18].

Several studies reported the role of lipoprotein apheresis in reducing the risk of recurrences in patients with coronary artery disease and high Lp(a) levels [19-21].

The assessment for the eventual presence of thrombophilia might become a useful tool to optimize cardiovascular risk stratification and therapy for high-risk selected patients [22]. 


\section{REFERENCES}

1. Anuurad $E$, Boffa $M B$, Koschinsky $M L$, Berglund L. Lipoprotein(a): a unique risk factor for cardiovascular disease. Clin Lab Med. 2006; 26: 751-772. Ref.: https://goo.gl/Q8XV9Z

2. Boffa MB, Marcovina SM, Koschinsky ML. Lipoprotein(a) as a risk factor for atherosclerosis and thrombosis: mechanistic insights from animal models. Clin Biochem. 2004; 37: 333-343. Ref.: https://goo.gl/Dm0jv3

3. Danesh J, Erqou S. Risk factors: Lipoprotein(a) and coronary disease-moving closer to causality. Nat Rev Cardiol. 2009; 6: 565-567. Ref.: https://goo.gl/fYG7J0

4. Emerging Risk Factors Collaboration, Erqou S, Kaptoge S, Perry PL, Di Angelantonio E, et al. Lipoprotein(a) concentration and the risk of coronary heart disease, stroke, and nonvascular mortality. JAMA. 2009; 302: 412-423. Ref.: https://goo.gl/6XVYRI

5. Sofi F, Marcucci R, Abbate R, Gensini GF, Prisco D. Lipoprotein (a) and venous thromboembolism in adults: a meta-analysis. Am J Med. 2007; 120: 728-733. Ref.: https://goo.gl/6sJAkk

6. Klingel R, Heibges A, Fassbender C. Lipoprotein apheresis results in plaque stabilization and prevention of cardiovascular events: comments on the prospective Pro(a)LiFe study. Clin Res Cardiol Suppl. 2015; 10: 46-50. Ref.: https://goo.gl/pJcLcy

7. Archontakis S, Pottle A, Hakim N, Ilsley C, Barbir M. LDL-apheresis: indications and clinical experience in a tertiary cardiac centre. Int J Clin Pract. 2007; 61: 1834-1842. Ref.: https://goo.gl/w1IKOa

8. European Stroke Organisation, Tendera M, Aboyans V, Bartelink ML, Baumgartner I, et al. ESC Guidelines on the diagnosis and treatment of peripheral artery diseases: Document covering atherosclerotic disease of extracranial carotid and vertebral, mesenteric, renal, upper and lower extremity arteries: the Task Force on the Diagnosis and Treatment of Peripheral Artery Diseases of the European Society of Cardiology (ESC). Eur Heart J. 2011; 32: 2851-2906. Ref.: https://goo.gl/8FSRsz

9. Schwartz J, Padmanabhan A, Aqui N, Balogun RA, Connelly-Smith L, et al. Guidelines on the Use of Therapeutic Apheresis in Clinical Practice-EvidenceBased Approach from the Writing Committee of the American Society for Apheresis: The Seventh Special Issue. J Clin Apher. 2016; 31: 149-162. Ref.: https://goo.gl/L5bl54

10. The HPS-THRIVE Collaborative Group, Landray MJ, Haynes R, Hopewell JC, Parish S. Effects of Extended-Release Niacin with Laropiprant in High-Risk Patients. N Engl J Med. 2014; 371: 203-212. Ref.: https://goo.gl/p8fvjj

11. Lim MY, Deal AM, Kim S, Musty MD, Conard J, et al. Thrombophilic Risk of Individuals with Rare Compound Factor V Leiden and Prothrombin G20210A Polymorphisms: An International CaseSeries of 100 Individuals. Eur J Haematol. 2016; 97: 353-360. Ref.: https://goo.gl/zGBkQa

12. Baglin T Gray E, Greaves M, Hunt BJ, Keeling D, Machin S, et al. Clinical guidelines for testing for heritable thrombophilia. Br J Haematol. 2010; 149: 209-220. Ref.: https://goo.gl/4DkCFV

13. Bates SM, Greer IA, Middeldorp S, Veenstra DL, Prabulos AM, et al. VTE, thrombophilia, antithrombotic therapy, and pregnancy: Antithrombotic Therapy and Prevention of Thrombosis, 9th ed. American College of Chest Physicians Evidence-Based Clinical Practice Guidelines. Chest. 2012; 141: 691S-736S. Ref.: https://goo.gl/JgkxfD

14. Brouwer JL, Lijfering WM, Ten Kate MK, Kluin-Nelemans HC, Veeger NJ, et al. High long-term absolute risk of recurrent venous thromboembolism in patients with hereditary deficiencies of protein S, protein C or antithrombin. Thromb Haemost. 2009; 101: 93-99. Ref.: https://goo.gl/2zTp7f

15. Puricel S, Lehner C, Oberhänsli $M$, Rutz $T$, Togni $M$, et al. Acute coronary syndrome in patients younger than 30 years--aetiologies, baseline characteristics and long-term clinical outcome. Swiss Med Wkly. 2013; 143: 13816. Ref.: https://goo.gl/i7lBzs

16. Heffernan KS, Karas RH, Patvardhan EA, Jafri H, Kuvin JT. Peripheral arterial tonometry for risk stratification in men with coronary artery disease. Clin Cardiol. 2010; 33: 94-98. Ref.: https://goo.gl/6meeF8

17. Poredos $P$, Jezovnik MK. Testing endothelial function and its clinical relevance. $J$ Atheroscler Thromb. 2013; 20: 1-8. Ref.: https://goo.gl/cjjnl6

18. Cai A, Li L, Zhang Y, Mo Y, Mai W, et al. Lipoprotein(a): a promising marker for residual cardiovascular risk assessment. Dis Markers. 2013; 35: 551-559. Ref.: https://goo.gl/zejdSa 
19. Roeseler E, Julius U, Heigl F, Spitthoever R, Heutling D, et al. Lipoprotein Apheresis for Lipoprotein(a)Associated Cardiovascular Disease: Prospective 5 Years of Follow-Up and Apo(a) Characterization. Arterioscler Thromb Vasc Biol. 2016; 36: 2019-2027. Ref.: https://goo.gl/gDVhwh

20. Klingel R, Heibges A, Fassbender C, Pro(a)LiFe-Study Group. Prevention of cardiovascular complications in patients with $\mathrm{Lp}(\mathrm{a})$-hyperlipoproteinemia and progressive cardiovascular disease by long-term lipoprotein apheresis according to German national guidelines. Clin Res Cardiol Suppl. 2017. Ref.: https://goo.gl/MNo4h3

21. Leebmann J, Roeseler E, Julius U, Heigl F, Spitthoever R, et al. Lipoprotein apheresis in patients with maximally tolerated lipid-lowering therapy, Lipoprotein(a)-hyperlipoproteinemia, and progressive cardiovascular disease: prospective observational multicenter study. Circulation. 2013; 128: 25672576. Ref.: https://goo.gl/xC7jNI

22. Frolow M, Drozdz A, Kowalewska A, Nizankowski R, Chlopicki S. Comprehensive assessment of vascular health in patients; towards endothelium-guided therapy. Pharmacol Rep. 2015; 67: 786-792. Ref.: https://goo.gl/q5ZUpl 